\title{
Characteristics of the soil microbial community in the forestland of Camellia oleifera
}

\author{
Peng Zhang ${ }^{1,2}$, Zhiyi Cui ${ }^{2}$, Mengqing Guo ${ }^{1}$, Ruchun Xi ${ }^{\text {Corresp. } 1,2,3}$ \\ ${ }^{1}$ South China Agricultural University, College of Forestry and Landscape Architecture, Guangzhou, Guangdong, China \\ 2 Chinese Academy of Forestry, Research Institute of Tropical Forestry, Guangzhou, Guangdong, China \\ 3 South China Agricultural University, Guangdong Key Laboratory for Innovative Development and Utilization of Forest Plant Germplasm, Guangzhou, \\ Guangdong, China \\ Corresponding Author: Ruchun Xi \\ Email address: xirc2006@scau.edu.cn
}

Understanding of the characteristics of soil microbial communities is helpful for forest ecosystem management and microbial utilization. The characteristics of the microbial communities in the soil beneath Camellia oleifera (C. oleifera), an important woody edible oil tree in China, have not been reported before. Thus, we used Illumina sequencing of $16 \mathrm{~S}$ and ITS rRNA genes to explore the richness and diversity of the microorganisms in $C$. oleifera forest land in South China. The physicochemical properties, enzyme activities and microbial biomass of the rhizosphere soil were higher than those of the non-rhizosphere soil. The carbon source utilization capacity of rhizosphere soil microorganisms was greater than that of non-rhizosphere soil microorganisms, and the highest utilization capacities were observed in summer. Ester and amino acid carbon sources played major roles in the functional principal component differentiation of the soil microbial community of $C$. oleifera. In summer, soil microbes were abundant in terms of species and functions. Rhizosphere microorganisms were more diverse than non-root systems. $\mathrm{pH}$, Available phosphorous (AP) and Urease (URE) were associated with the soil microbial community. These results indicated that microbial resources were richer in rhizosphere soil. The rhizosphere microorganisms in the growing season should be given priority in the development and utilization of soil microorganisms in $C$. oleifera plantation. It is possible to promote the growth of $C$. oleifera by controlling the carbon source species of soil, $p H, A P$, URE, etc. Overall, our findings provide valuable information to guide microbial isolation and culturing to manage $C$. oleifera land. 
1 Characteristics of the soil microbial community in the

\section{forestland of Camellia oleifera}

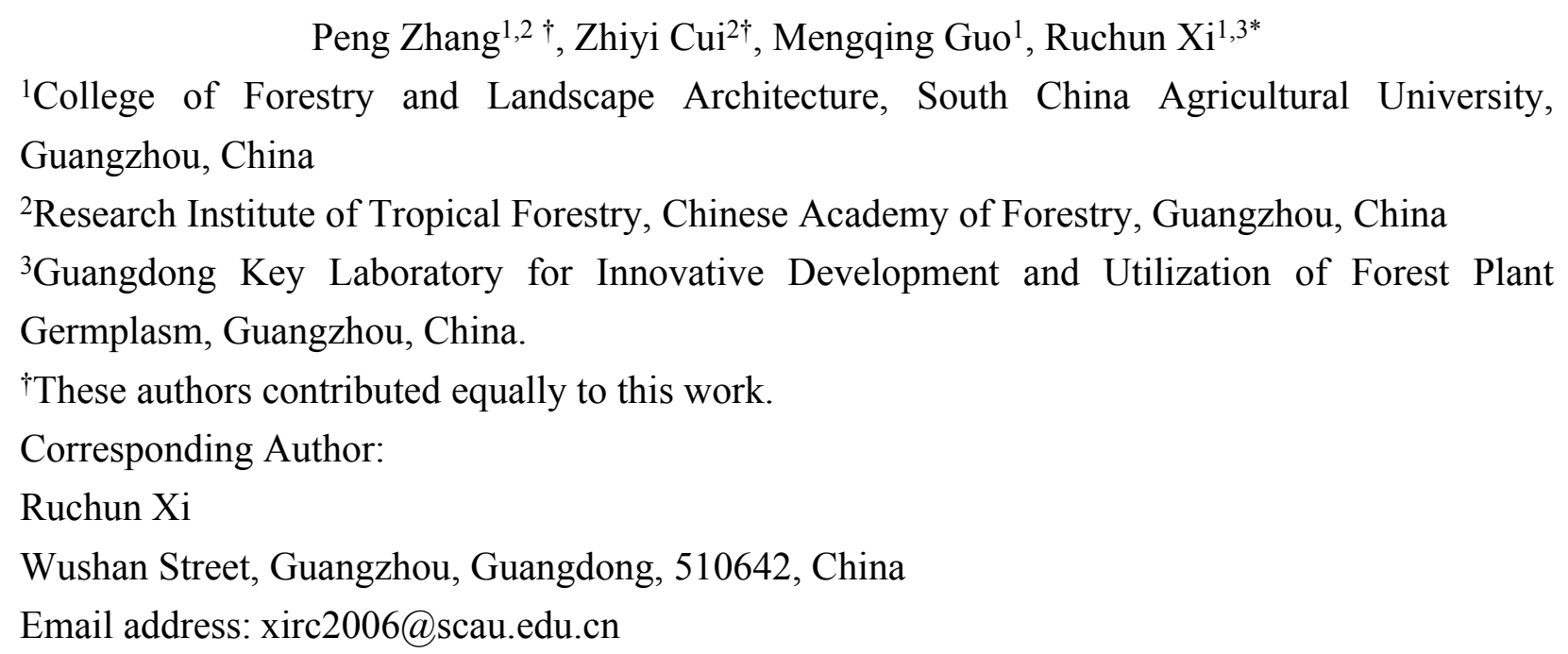

\section{Abstract}

Characterizing soil microbial community is important for forest ecosystem management and microbial utilization. The microbial community in the soil beneath Camellia oleifera, an important woody edible oil tree in China, has not been reported before. Here, we used Illumina sequencing of $16 \mathrm{~S}$ and ITS rRNA genes to study the species diversity of microorganisms in $C$. oleifera forest land in South China. The results showed that the rhizosphere soil had higher physicochemical properties, enzyme activities and microbial biomass than did the nonrhizosphere soil. The rhizosphere soil microorganisms had a higher carbon source utilization capacity than the non-rhizosphere soil microorganisms, and attained the highest utilization capacity in summer. The soil microbial community of $C$. oleifera was characterized by rich ester and amino acid carbon sources that played major roles in the principal functional components of the community. In summer, soil microbes were abundant in species richness and very active in community function. Rhizosphere microorganisms were more diverse than non-root systems in species diversity, which was associated with soil $\mathrm{pH}$, Available phosphorous (AP) and Urease (URE). These results indicated that microbial resources were rich in rhizosphere soil. A priority should be given to the rhizosphere microorganisms in the growing season in developing and utilizing soil microorganisms in $C$. oleifera plantation. It is possible to promote the growth of $C$. oleifera by changing soil microbial community, including carbon source species, $\mathrm{pH}$, AP, and URE. Our findings provide valuable information to guide microbial isolation and culturing to 
manage $C$. oleifera land.

\section{Introduction}

Photosynthetically fixed compounds are released into the soil, especially rhizosphere soil, through root exudates and plant residues by green plants (Hütsch et al., 2002; Shah et al., 2016). These compounds are the energy and carbon sources of soil microorganisms. Soil microorganisms, in turn, exploit inorganic, organic and atmospheric forms of nutrients for plant growth (Shah et al., 2016). Microorganisms participate in biochemical processes such as soil ammoniation and nitrification, by promoting soil organic matter decomposition and nutrient conversion, and they are the primary drivers of biochemical cycles (Moreau et al., 2019). They play extremely important roles in the formation of soil fertility and the transformation of plant nutrients.

Microbial community structure characteristics refer to the species composition and abundance of microbial communities (Ochoa-Hueso et al., 2018). An increase in the soil microbial community structure and composition diversity helps to maintain the stability of the soil ecosystem and enhances the resistant capacity of soil against environmental degradation (Cheng et al., 2017). Studies has been made toward the characterization of soil microbiomes in some plant species, including Arabidopsis (Bulgarelli et al., 2012), rice (Edwards et al., 2015), Eucalyptus saligna (Curlevski et al.,2014), and Populus (Gottel et al., 2011).

Camellia oleifera (C. oleifera), a unique edible oil tree species in China, is one of the world's four famous woody oil plants (Jia et al., 2015; Zhou et al., 2019). Its unsaturated fatty acid content is higher than $90 \%$ (Wu et al., 2019); this species have strong anti-oxidation and free radical scavenging ability and the effect of preventing cardiovascular diseases. The history of C. oleifera cultivation in China is over 2300 years (He et al., 2011), and the current areas of cultivation in China are predicted to grow to 4.67 million ha by 2020 (Liu et al., 2017). C. oleifera is not only an excellent economic tree but also an excellent ecological tree (Wang et al., 2007). C. oleifera generally grows in the mountains and hills of subtropical regions in southern China and is also of great value in soil and water conservation and maintaining ecological balance.

The method of laboratory culture has been used to study soil microorganisms of C. oleifera (Liu et al., 2017; Liu et al., 2018; Lu et al., 2019). These studies revealed the number and types of soil microbial communities in C. oleifera in different seasons. However, this approach lacks precision, and many community characteristics had not been explored. Instead, high throughput sequencing can be more powerful to investigate soil microbial community structure. To our knowledge, high-throughput sequencing methods have not been used in the study on the 
characteristics of the soil microbial community in $C$. oleifera forest land. Obtaining such information in the production and management of the $C$. oleifera forest ecosystem will be valuable in soil management and microbial utilization in the future. Due to rhizosphere effect, there are more microorganisms in rhizosphere soil than in non-rhizosphere soil. Rhizosphere microbes, which are considered to be part of the second genome of plants, play a fundamental role in plant growth and health. We hypothesized that $C$. oleifera have a "rhizosphere effect", and the nutrient characteristics of rhizosphere soil is better than non-rhizosphere soil.

\section{Materials \& Methods}

Site description

The research area is located in Fengren, Longchuan, Heyuan, Guangdong, China $\left(24^{\circ} 13^{\prime} 38^{\prime \prime} \mathrm{N}, 115^{\circ} 20^{\prime} 18^{\prime \prime} \mathrm{E}\right)$. The average altitude is $154 \mathrm{~m}$. The average annual temperature is $21.8^{\circ} \mathrm{C}$, and annual rainfall is $1501.8 \mathrm{~mm}$ (http://www.tianqi.com/qiwen/city_longchuan/, in Chinese). The soil is categorized as haplic acrisols according to the FAO soil classification. The C. oleifera forest was cultivated in the early 1960s, and there is no artificial disturbance except the annual harvest. The height of forest is $(3.71 \pm 1.08) \mathrm{m}$, the crown diameter is $(4.47 \pm 1.15) \mathrm{m}$, and the ground diameter is $(8.23 \pm 3.49) \mathrm{cm}$.

Sample collection

Six $20 \mathrm{~m} \times 20 \mathrm{~m}$ sample plots were randomly set in the experimental area. In April 2018 (spring), July 2018 (summer), October (autumn) and January 2019 (winter), soil samples were collected at each sample site under sunny conditions.

Fifteen healthy $C$. oleifera trees were selected from each plot. The rhizosphere and nonrhizosphere soil samples were collected as described by $\mathrm{Xu}$ et al. (2018). The rhizosphere and non-rhizosphere soil samples from the same grove were mixed together as one sample for each plot. The top 5-cm of soil was removed, and fine roots (approximately $1 \mathrm{~mm}$ diameter) from a depth of 5-15 cm were collected. The roots were removed from the soil with a shovel and then gently shaken to remove the soil that was not tightly attached to the roots. The rhizosphere soil was obtained by gently brushing the soil on the root surface with a sterile brush. Soil collected from the same 5-15 cm depth in locations between trees and without roots was termed nonrhizosphere soil. The samples were stored in liquid nitrogen and transported to the laboratory for refrigeration.

Measurement methods

Soil property analysis

Soil texture was measured as described by Will et al. (2010). The $\mathrm{pH}$ was measured in soil of water suspension with a ratio of 1:2.5 using glass electrode $\mathrm{pH}$ meter; the content of organic matter $(\mathrm{OM})$ was determined by the high-temperature external heat dichromate oxidation- 
capacity method (Schinner et al., 1995); alkali hydrolysis (AN) was used in the determination of alkali hydrolysis nitrogen by the alkali-hydrolysis diffusion method (Ming et al., 2011); and the available phosphorous (AP) was extracted by ammonium hydrochloride and determined by the molybdenum antimony colorimetric method (Olsen and Sommers., 1982).

Cellulase (beta-glucosamine) (CEL) activity was determined using the salicylic glycosides colorimetric method (Miller G L.,1959); urea enzyme (URE) was determined using the sodium phenol colorimetric method (Bell et al., 2013); and acid phosphatase (ACP) was determined using the benzene diphosphate colorimetric method (Lu., 2000).

Soil microbial biomass carbon (MBC), nitrogen (MBN) and phosphorus (MBP) were extracted by chloroform fumigation (Vance et al., 1987; Petersen et al., 2003).

Soil microbial functional diversity analysis

Soil microbial metabolic activity was measured using Biolog Eco-microplates (Garland, 1997). Carbon utilization by microorganisms caused colour development in the wells. The colour development in each well was recorded at an optical density of $590 \mathrm{~nm}$ at $24 \mathrm{~h}$ intervals for 168 $\mathrm{h}$. The different carbon sources of soil microorganism utilization were analysed in 120 hours. Soil microbial community characteristics analysis

The 16 s rRNA V3-V4 region of bacteria and the internal transcribed spacer (ITS) region of fungi were used as the target sequences of DNA. The PCR amplification was carried out with the universal primer pairs of 338F (5'- ACTCCTACGGGAGCAGCAG -3') and 806R (5'GGACTACHGGG TWTCTAAT-3'), and ITS1F (5'- CTTGGTCATTTAGGAAGTAA-3') and ITS2R (5'- GCTGCGTTC TTCATCATGATGC -3'), respectively (Biddle et al., 2008; Mukherjee et al., 2014). The $20 \mu \mathrm{L}$ PCR amplification reaction material comprised of $4 \mu \mathrm{L}$ of 5 $\times$ FastPfu Buffer (16 s v3-v4)/2 $\mu$ L of $10 \times$ Buffer (ITS), $2 \mu \mathrm{L}$ dNTPs $(2.5 \mathrm{mM}), 0.8 \mu \mathrm{L}$ each of forward and reverse primers, $0.4 \mu \mathrm{L}$ of FastPfu Polymerase (16S v3-v4)/0.2 $\mu \mathrm{L}$ of rTaq Polymerase (ITS), $0.2 \mu \mathrm{L}$ of BSA, and $10 \mathrm{ng}$ template DNA. Each of these was supplemented with $\mathrm{ddH}_{2} \mathrm{O}$ up to $20 \mu \mathrm{L}$

Polymerase chain reaction (PCR) amplification followed a specific thermal program: an initial denaturation at $95{ }^{\circ} \mathrm{C}$ for $3 \mathrm{~min}$, followed by 28 cycles of denaturation at $95{ }^{\circ} \mathrm{C}$ for $30 \mathrm{~s}$, annealing at $55^{\circ} \mathrm{C}$ for $30 \mathrm{~s}$, and elongation at $72{ }^{\circ} \mathrm{C}$ for $45 \mathrm{~s}$, and a final extension at $72{ }^{\circ} \mathrm{C}$ for 10 min. Three repeated PCR products from the same sample were mixed and detected by $2 \%$ agarose gel electrophoresis. The samples with bright main bands between $400 \mathrm{bp}$ and $450 \mathrm{bp}$ were selected for further analysis. The PCR products were recovered and purified by the AxyPrep $^{\mathrm{TM}}$ DNA Gel Extraction Kit (Axygen Biosciences, Union City, CA, USA) and quantified using a QuantiFluor ${ }^{\circledR}-S T$ Fluorometer (Promega, USA). Finally, the Illumina pairend library preparation, cluster generation and $250 \mathrm{bp}$ pair-end sequencing were determined by Majorbio Bio-Pharm Technology Co. Ltd. (Shanghai, China). 


\section{Data analysis}

QIIME v1.7.0 was used to depolymerize, quality filter and analyse the raw Illumina sequences and to obtain high quality tags data. After comparison with GOLD (Genomes Online Database), the detected chimera sequence was removed to obtain valid tags data. The sequence obtained was clustered into operational taxonomic units (OTUs) according to the similarity level using UPARSE Pipeline v 7.0 at a threshold of $97 \%$ classification. The representative sequences in OTUs were then selected and compared with the known sequence in the database to obtain the species annotation information (Zhang et al., 2019).

SPSS Statistics 22.0 was used for one-way ANOVA, multiple comparisons, and principal component analysis. Hierarchical clustering was used to assess similarity characteristics soil based on the unweighted pair group arithmetic average (UPGMA). Unweighted Principal Coordinates Analysis (PCoA) of microbial community data was performed using the vegan package of $\mathrm{R}$.

\section{Results}

Soil physicochemical properties, enzyme activities and microbial biomass

In the four seasons, the rhizosphere soil $\mathrm{pH}$ was lower than that of the non-rhizosphere soil, and the $\mathrm{OM}$ and AN and AP contents of the rhizosphere soil were significantly higher than these of non-rhizosphere soil (Table 1). The $\mathrm{pH}$ of rhizosphere and non-rhizosphere soil of C. oleifera were the lowest in summer. The content of OM, AN and AP were the highest in summer or autumn.

Cellulase and acid phosphatase in rhizosphere and non-rhizosphere soils were most active in summer, whereas the highest activity of urease was observed in autumn. There were significant differences in soil enzyme activity between rhizosphere and non-rhizosphere soils in each season.

The highest contents of microbial biomass carbon, nitrogen and phosphorus in the rhizosphere and non-rhizosphere soils were found in summer. There were significant differences in the microbial biomass content between rhizosphere and non-rhizosphere soils in each season.

Soil microbial functional diversity

Kinetic characteristics of soil microbial utilization of all carbon sources

By the time before $24 \mathrm{~h}$, average well colour development (AWCD) values were very low, less than 0.051 (Fig.1), which means that the microbial activity was weak, and the carbon source was basically not consumed. Between $24 \mathrm{~h}$ and $144 \mathrm{~h}$, AWCD values increased rapidly, indicating that the carbon source was heavily utilized after $24 \mathrm{~h}$. In the same season, the AWCD values of rhizosphere soil were higher than those of non-rhizosphere soil in each culture period, indicating higher carbon source utilization and stronger metabolic activity of the rhizosphere microbial community. Within one year, the carbon source capacity for the rhizosphere soil and 
the non-rhizosphere soil was consistent, from summer to autumn, spring and winter. Types of carbon sources used by soil microbial communities

In annual, six major types of carbon sources were utilized by rhizosphere soil microbial communities (Fig. 2). However, the average utilization of various carbon sources was different. In summer, the average utilization of various carbon sources in the rhizosphere soil microbial community was from esters, alcohols, acids, amines, amino acids and sugars. The average utilization degree of non-rhizosphere soil microbial communities with respect to various carbon sources was esters, acids, alcohols, amino acids, sugars and amines.

Soil microbial community characteristics

Sequencing data statistics

The number of effective sequences of bacteria and fungi were 29,570-63,373 and 31,82465,373, respectively (Fig. 3). The curve gradually flattened, and the sequencing quantity tended to saturate. This indicates that the construction of the library was reasonable, and the sampling depth of bacteria and fungi was sufficient for the species diversity.

In total, 550 species of bacteria were detected in rhizosphere and non-rhizosphere soils, belonging to 26 families, 60 classes, 119 orders, 206 families, 297 genera. A total of 6 families, 23 classes, 71 orders, 139 families, 215 genera and 292 species of fungi were obtained.

Sample comparative analysis

According to the hierarchical clustering tree and principal component analysis (Fig. 4 and 5), we knew that among rhizosphere soil and non-rhizosphere soil, the bacterial composition and structure of soil were very similar (Fig. 4a and 5a), and there were some differences in fungal composition between rhizosphere soil and non-rhizosphere soil (Fig. $4 \mathrm{~b}$ and 5b). Especially, two outlier fungal communities (N5 and N6) were the outliers in the PCAs.

Species composition analysis

\section{Analysis of species Venn diagram}

A total of 1936 OTUs were classified into bacterial communities (Fig. 6). Among them, the number of OTUs in rhizosphere and non-rhizosphere soils was 308 and 137, and the total number of OTUs in rhizosphere and non-rhizosphere soils was 1491 (Fig. 6a). Fungi were classified into 1068 OTUs. Among them, the number of OTUs in rhizosphere and nonrhizosphere soil was 517 and 159, and the total number of OTUs was 392 (Fig. 6b). Community composition analysis

\section{Community structure at the phylum classification level}

According to the Bar map of the community, we knew that at the phylogenetic level, soil bacteria in each sample belonged to 26 phyla, of which 12 phyla were found in rhizosphere and non-rhizosphere soils with a relative abundance higher than 1\% (Fig. 7a). Soil fungi in each 
211 sample belonged to 12 phyla, of which 4 phyla were found in rhizosphere and non-rhizosphere

212 soils with a relative abundance higher than $1 \%$ (Fig. $7 b$ ).

213 Community structure at the genus classification level

In total, 297 genera of bacteria were obtained from soil samples, and 50 genera were found in rhizosphere and non-rhizosphere soils with abundances higher than 1\% (Fig. 8a). The 14 dominant species in the rhizosphere soil accounted for $53.62 \%$ of the total abundance. The 14 dominant species of non-rhizosphere soil samples accounted for $76.14 \%$ of the total abundances.

In total, 215 genera of fungi were obtained from soil samples, and 26 genera were found in rhizosphere and non-rhizosphere soils with abundances higher than $1 \%$ (Fig. 8b). The 8 dominant species in the rhizosphere soil accounted for $89.25 \%$ of the total abundance. The 5 dominant species of non-rhizosphere soil samples accounted for $89.64 \%$ of the total abundance. Correlation analysis of community structure and environmental factors

The environmental factors $\mathrm{pH}$ and $\mathrm{AP}$ were associated with the soil bacterial community (Fig. 9a). The higher the $\mathrm{pH}$ value is, the lower the bacterial community abundance would be, and when the content of AP was the highest, the abundance of bacteria community was the highest. For the soil fungal community, the environmental factors $\mathrm{pH}$ and URE were associated with the soil fungal community (Fig. 9b). The higher the $\mathrm{pH}$ value is, the lower the fungal abundance would be, and the greater the URE activity is, the higher the fungal community abundance would be.

\section{Discussion}

C. oleifera is often planted in mountainous areas with poor site conditions, and fertilization and other management measures lag behind. Therefore, the study of soil nutrient characteristics and soil microbial community characteristics of $C$. oleifera is of great helpful to the soil management of this species. Soil nutrient is significantly affected by soil microbes through mineralization and nutrient retention (Zhang et al., 2018; Shao et al., 2019). In this study, the $\mathrm{pH}$ value in the rhizosphere soil of $C$. oleifera was lower than that in the non-rhizosphere soil, and the content of OM, AN and AP in the rhizosphere soil was significantly higher than that in the non-rhizosphere soil. This reflects the nutrient enrichment effect of $C$. oleifera rhizosphere, and C. oleifera, Malus pumila, Pseudotsuga menziesii, Fagus sylvatica, Helianthus annuus and other plants have a strong "rhizosphere effect" (Dong et al.,2001; Fu et al., 2004; Augustine et al., 2011; Calvaruso et al., 2011; Dotaniya et al., 2015; De Feudis et al., 2016). It is well known that soil biological (microbial and enzymatic) activities are highly correlated with soil physicochemical properties and also participate in the conversion of soil nutrients (Gispert et al., 2013). The activity of soil enzymes in the $C$. oleifera system was generally higher in summer and autumn and lower in winter during the dormant period. All biochemical transformations in 
246 soil are facilitated by enzymes; they can promote the transformation of soil nutrients and accelerate the soil nutrient cycle (Hoang et al., 2016). However, the growing season is the period in which plants have the greatest demand for nutrients. Additionally, MBC, MBN and MBP are usually regarded as indicators of microbial nutrient requirements and nutrient availability (Dijkstra et al., 2012; Mooshammer et al., 2017). C, N and P contents in microbial biomass were the highest in summer, and these results are in line with several previous findings (Alongi et al., 1988; Bardgett et al., 1999; Chen et al., 2015; Zifčáková et al., 2016; Spohn et al., 2018). Due to the presence of soil rhizosphere microorganisms, the soil quality in the rhizosphere of $C$. oleifera is superior to non-rhizosphere soil, which is more conducive to the growth of $C$. oleifera. In other words, it is of great significance for the development and utilization of the rhizosphere microorganisms of C. oleifera.

The pattern of Biolog metabolic diversity is related to microbial community composition and is sensitive to the change of the functional microbial community (Rogers et al., 2001). The AWCD reflects the integrated capability of soil microbes to use a carbon source and the microbial activity (Wang et al., 2016). This study showed that the metabolic activity of the rhizosphere microbial community was stronger than that of non-rhizosphere soil microorganisms, and the use of carbon sources in summer was higher than that in the other seasons. Based on the utilization of six kinds of carbon sources, rhizosphere soil and non-rhizosphere soil microorganisms made greater use of ester and amino carbon sources. In production practice, understanding the functional of microbial community has positive significance for the soil management of $C$. oleifera during the four seasons.

Many microbial species are same in rhizosphere and non-rhizosphere soil, but some are different. Rhizosphere soil microbial community diversity was higher than that in nonrhizosphere soil. This also means that the ability of rhizosphere soil to resist the change of the external environment is stronger, and its soil ecological environment is more stable (Guo et al., 2018; Xia et al., 2018). Microbial community diversity of non-rhizosphere soil was lower than rhizosphere soil. Especially, there were very few fungal species in some samples. The probable reason may be non-rhizosphere soil lack of diverse substrates. And this result was possible caused by experimental problems in sequencing. The reason of the formation in the forestland of C. oleifera deserve further studied.

Chloroflexi, Proteobacteria, Acidobacteria, Actinobacteria and Planctomycetes were the dominant groups of the bacterial community of C. oleifera. Ascomycota, Basidiomycota, etc., were the dominant groups of the fungal community of $C$. oleifera. The dominant species of $C$. oleifera soil have similarities with the soil of many woodlands (Youssef et al., 2009; Frac et al., 2018; Prieto-Barajas et al., 2018; Egidi et al., 2019). Chloroflexi, Proteobacteria, Actinobacteria and Planctomycetes bacteria can catalyze nitrification that promotes of the biogeochemical 
282 nitrogen cycle process (Kong et al., 2005; Hayatsu et al., 2008; Sorokin et al., 2012; Shridhar et 283 al.,2012). Acidobacteria bacteria is beneficial to plant growth in acid soil (Yang et al., 2012). 284 Ascomycota, and Basidiomycota fungal can form mycorrhiza in symbiosis with plants, and 285 benefit to plant nutrition absorption and growth (Toju et al., 2013). These dominant microbial 286 groups play important roles in the function of C. oleifera soil.

The environmental factors $\mathrm{pH}$ and AP were associated with the soil bacterial community. For the soil fungal community, the associated environmental factors were $\mathrm{pH}$ and URE. During the last years, several studies targeting soil microbial communities came to the same conclusion that soil $\mathrm{pH}$ is the major driver of microbial communities (Lauber et al., 2013; Kaiser et al., 2016). A range of root exudates may alter the diversity and abundance of carbohydrate inputs into soil, as well as soil $\mathrm{pH}, \mathrm{AP}$ and URE, which is an important driver of soil microbial community diversity and structure. It means that management of soil physical and chemical properties can affect microbial community structure. Also, this provides a direction for enhancing plant growth and productivity.

In summer, the growth season that is the most abundant in terms of microbial species, soil microorganisms have the greatest impact on plant nutrient and water absorption and utilization (Žifčáková L, et al., 2016). There are some differences in soil microbial community characteristics and composition in different distribution areas and seasons. In future research, the distribution area of the study can be expanded to the whole country, and annual dynamic changes of soil microbial community characteristics can be further studied. It is beneficial to understand the relationship between soil microorganisms and $C$. oleifera and its cultivation and management. At the same time, there are many unclassified and abundant microbial populations in the soil of of unknown microorganisms are important to soil microbial community study. It would benefit to the development and utilization of microbial resources.

\section{Conclusions}

In this study, we found that the nutrient conversion and carbon source utilization ability of the rhizosphere microflora of $C$. oleifera was superior to non-rhizosphere soil. When developing and utilizing the soil microorganisms of $C$. oleifera, the use of rhizosphere microorganisms can be given priority, especially in the growing season. In future management of forest land, it is possible to promote the growth of $C$. oleifera by controlling the carbon source species in soil and the soil physicochemical properties.

\section{Acknowledgements}


315

316

317

318

319

320

321

322

323

324

325

326

327

328

We are grateful to Mengqing Guo, who helped in the experiments. We thank the National Key Research and Development Program of China (NO.2018YFD1000603) supported this work.

\section{Data availability}

The raw sequencing reads were deposited in the NCBI Bioproject database under the accession number PRJNA592248.

\section{References}

Alongi DM.1988. Bacterial productivity and microbial biomass in tropical mangrove sediments. Microbial Ecology 15:59-79 https://doi.org/10.1007/BF02012952.

Augustine DJ, Dijkstra FA, Hamilton III EW, Morgan JA.2011. Rhizosphere interactions, carbon allocation, and nitrogen acquisition of two perennial north american grasses in response to defoliation and elevated atmospheric co2. Oecologia 165:755-770 10.1007/s00442-010-1845-4.

Bardgett RD, Lovell RD, Hobbs PJ, Jarvis SC.1999. Seasonal changes in soil microbial communities along a fertility gradient of temperate grasslands. Soil Biology and Biochemistry 31:1021-1030 https://doi.org/10.1016/S0038-0717(99)00016-4.

Bell CW, Fricks BE, Rocca JD, Steinweg JM, McMahon SK, Wallenstein MD. 2013. Highthroughput fluorometric measurement of potential soil extracellular enzyme activities. JoVE 81:e5096 10.3791/50961 (2013).

Biddle JF, Fitz-Gibbon S, Schuster SC, Brenchley JE, House CH.2008. Metagenomic signatures of the Peru Margin subseafloor biosphere show a genetically distinct environment. Proceedings of the National Academy of Sciences 105: 10583-10588 https://doi.org/10.1073/ pnas.0709942105.

Bulgarelli D, Rott M, Schlaeppi K, van Themaat E V L, Ahmadinejad N, Assenza F, Rauf P, Huettel B, Reinhardt R, Schmelzer E, Peplies J, Gloeckner FO, Amann R, Eickhorst T, Schulze-Lefert P. 2012. Revealing structure and assembly cues for arabidopsis rootinhabiting bacterial microbiota. Nature 488:91-95 https://doi.org/ 10.1038/nature11336.

Calvaruso C, N'Dira V, Turpault M P.2011. Impact of common european tree species and douglas-fir (pseudotsuga menziesii[mirb.] Franco) on the physicochemical properties of the rhizosphere. Plant and Soil 342:465-480 https://doi.org/10.1007/s11104-010-0710-x.

Chen X, Wang D, Chen X,Wang J,Diao J, Zhang J, Guan Q.2015. Soil microbial functional diversity and biomass as affected by different thinning intensities in a chinese fir plantation. Applied Soil Ecology 92:35-44 https://doi.org/10.1016/j.apsoil.2015.01. 018.

Chen, Z, Zhang F, Gale WJ, Wang W, Sang W, Yang, H. 2017. Effects of reclamation years 
on composition and diversity of soil bacterial communities in Northwest China. Canadian journal of microbiology 64:28-40 https://doi.org/10.1139/ cjm-2017-0362.

Curlevski N, Drigo B, Cairney J, Anderson I. 2014. Influence of elevated atmospheric CO2 and water availability on soil fungal communities under Eucalyptus saligna. Soil Biology and Biochemistry 70:263-271 https://doi.org/10.1016/j.soilbio.2013.12.010.

De Feudis M, Cardelli V, Massaccesi L, Bol R, Willbold S, Cocco S, Corti G, Agnelli A. 2016. Effect of beech (Fagus sylvatica L.) rhizosphere on phosphorous availability in soils at different altitudes (Central Italy). Geoderma 276:53-63 https:// doi.org/ 10.1016/j.geoderma. 2016.04.028.

Dijkstra FA, Pendall E, Morgan JA, Blumenthal DM, Carrillo Y, LeCain DR, Follett RF, Williams DG. 2012. Climate change alters stoichiometry of phosphorus and nitrogen in a semiarid grassland. New Phytologist 196:807-815 https://doi.org/10. 1111/j.14698137.2012.0 4349.x.

Dong S, Shu H.2001. Effects of different nitrogen fertilizers on the rhizosphere of apple seedlings. International Society for Horticultural Science 564:371-377 10.17660/ActaHortic.2001.564. 46.

Dotaniya ML, Meena VD.2015. Rhizosphere effect on nutrient availability in soil and its uptake by plants: a review. Proceedings of the National Academy of Sciences. India Section B: Biological Sciences 85:1-12 https://doi.org/10.1007/s40011-013-0297-0.

Edwards J, Johnson C, Santos-Medellín C, Lurie E, Podishetty NK, Bhatnagar S, Eisen JA, Sundaresan V. 2015. Structure, variation, and assembly of the root-associated microbiomes of rice. Proceedings of the National Academy of Sciences of the United States of America 112: E911-E920 https://doi.org/10.1073/pnas.1414592112.

Egidi E, Delgado-Baquerizo M, Plett JM, Wang J, Eldridge DJ, Bardgett RD, Maestre FT, Singh BK.2019. A few ascomycota taxa dominate soil fungal communities worldwide. Nature Communications 111:2369-2378 https://doi.org/10. 1038/s41467-019-10373-z.

Frac M, Hannula SE, Bełka M, Jędryczka M. 2018. Fungal biodiversity and their role in soil health. Frontiers in Microbiology 9:707-716 https://doi.org/10.3389/fmicb. 2018.00707.

Fu S, Cheng W. 2004. Defoliation affects rhizosphere respiration and rhizosphere priming effect on decomposition of soil organic matter under a sunflower species.: Helianthus annuus. Plant and Soil 263:345-352 https://doi.org/10.1023/B:PLSO. 0000047745. 30929.32.

Garland JL. 1997. Analysis and interpretation of community-level physiological profiles in microbial ecology. FEMS microbiology ecology 24:289-300 https://oi.org/ 10.1111/j.15746941.1997.tb00446.x

Gottel NR, Castro HF, Kerley M, Yang Z, Pelletier DA, Podar M, Karpinets T, Uberbacher E, Tuskan GA, Vilgalys R, Doktycz MJ, Schadt CW.2011. Distinct 
microbial communities within the endosphere and rhizosphere of populus deltoides roots across contrasting soil types. Applied and Environmental Microbiology 77:5934-5944 10.1128/AEM.05255-11.

Guo Y, Chen X, Wu Y, Zhang L, Cheng J, Wei G, Lin Y. 2018. Natural revegetation of a semiarid habitat alters taxonomic and functional diversity of soil microbial communities. Science of The Total Environment 635:598-606 https://doi.org/10.1016/j.scitotenv.2018.04. 171.

Hayatsu M, Tago K, Saito M. 2008. Various players in the nitrogen cycle: diversity and functions of the microorganisms involved in nitrification and denitrification. Soil Science and Plant Nutrition 54: 33-45 https://doi.org/10.1111/j.1747-0765.2007.00195.x.

He G, Zhang J, Hu X, Wu J. 2011. Effect of aluminum toxicity and phosphorus deficiency on the growth and photosynthesis of oil tea (camellia oleifera Abel.) Seedlings in acidic red soils. Acta Physiologiae Plantarum 33:1285-1292 https://doi. org/10.1007/s11738-0100659-7.

Hoang DT, Razavi BS, Kuzyakov Y, Blagodatskaya E. 2016. Earthworm burrows: kinetics and spatial distribution of enzymes of C-, N- and P- cycles. Soil Biology and Biochemistry 99:94-103 https://doi.org/10.1016/j.soilbio.2016.04.021.

Hütsch BW, Augustin J, Merbach, W. 2002.Plant rhizodeposition: an important source for carbon turnover in soils. Journal of Plant Nutrition and Soil Science 165:397-407 https://doi.org/10.1002/1522-2624(200208)165:4<397::AID-JPLN397>3.0.CO;2-C.

Jia BG, Lin Q, Feng YZ, Hu XY, Tan XF, Shao FG, Zhang L. 2015. Development and cross-species transferability of unigene-derived microsatellite markers in an edible oil woody plant, camellia oleifera (theaceae). Genetics and Molecular Research 14:6906-6916 http://dx.doi.org/10.4238/2015.June.18.33.

Kaiser K, Wemheuer B, Vera Korolkow V, Wemheue F, Nacke H, Schöning I, Schrump M, Daniel R. 2016. Driving forces of soil bacterial community structure, diversity, and function in temperate grasslands and forests. Nature 6:33696-33708 10.1038/srep33696.

Kong Y, Nielsen $\mathbf{J}$ L, Nielsen $\mathbf{P}$ H. 2005. Identity and ecophysiology of uncultured actinobacterial polyphosphate-accumulating organisms in full-scale enhanced biological phosphorus removal plants. Appl. Environ. Microbiol 71: 4076-4085 10.1128/AEM.71.7.4076-4085.2005.

Lauber CL, Hamady M, Knight R, Fierer N. 2013. Pyrosequencing-based assessment of soil ph as a predictor of soil bacterial community structure at the continental scale. Appl Environ Microbiol 7:1641-1650 10.1128/AEM.00335-09.

Liu J, Wu L, Chen D, Li M, Wei C. 2017. Soil quality assessment of different camellia oleifera stands in mid-subtropical china. Applied Soil Ecology 113:29-35 https://doi.org/10.1016 
/j.apsoil.2017.01.010.

Liu J, Wu L, Chen D, Yu ZG, Wei CJ. 2018. Development of a soil quality index for camellia oleifera forestland yield under three different parent materials in southern china. Soil \& Tillage Research 176:45-50 https://doi.org/10.1016/j.still.2017.09.013.

Lu RK. 2000. Methods of Soil and Agro-chemical Analysis. Beijing: China Agricultural Science and Technology Press.

Gispert M, Emran M, Pardini G, Doni S, Ceccanti B.2013. The impact of land management and abandonment on soil enzymatic activity, glomalin content and aggregate stability. Geoderma 202:51-61 https://doi.org/10.1016/j.geoderma.2013.03. 012.

Ming L I U, Klemens E, Zhang B. 2011. Effect of intensive inorganic fertilizer application on microbial properties in a paddy soil of subtropical China. Agricultural Sciences in China 10: 1758-1764 https://doi.org/10.1016/S1671-2927(11)60175-2.

Miller G L. 1959. Use of dinitrosalicylic acid reagent for determination of reducing sugar[J]. Analytical chemistry 31: 426-428 https://doi.org/10.1021/ac60147a030.

Mooshammer M, Hofhansl F, Frank AH, Wanek W, Hämmerle I, Leitner S, Jörg Schnecker J, Wild B, Watzka M, Keiblinger KM, Zechmeister-Boltenstern S, Richter A.2017. Decoupling of microbial carbon, nitrogen, and phosphorus cycling in response to extreme temperature events. Science advances 3:e1602781 10.1126/sciadv. 1602781.

Moreau D, Bardgett RD, Finlay RD, Jones DL, Philippot L.2019. A plant perspective on nitrogen cycling in the rhizosphere. Functional Ecology 33:540-552 https://doi.org/ 10.111 /1365-2435.13303.

Mukherjee PK, Chandra J, Retuerto M, Sikaroodi M, Brown RE, Jurevic R.2014. Oral mycobiome analysis of HIV-infected patients: identification of Pichia as an antagonist of opportunistic fungi. PLoS Pathog 10:e1003996 https://doi.org/10. 1371/journal.ppat.1003996.

Ochoa-Hueso R, Collins SL, Delgado-Baquerizo M, Hamonts K, Pockman WT, Sinsabaugh RL, Smith MD, Knapp AK, Power SA. 2018. Drought consistently alters the composition of soil fungal and bacterial communities in grasslands from two continents. Global change biology 24:2818-2827 https://doi.org/10.1111/gcb.14113.

Olsen SR, Sommers LE. 1982. Phosphorus. In: Miller RH, Keeney DR, ed. Methods of Soil Analysis. Madison: American Society of Agronomy, 403-430.

Petersen SO, Petersen J, Rubæk GH. 2003. Dynamics and plant uptake of nitrogen and phosphorus in soil amended with sewage sludge. Applied Soil Ecology 24: 187- 195 https://doi.org/10.1016/S0929-1393(03)00087-8.

Prieto-Barajas CM, Valencia-Cantero E, Santoyo G. 2018. Microbial mat ecosystems: structure types, functional diversity, and biotechnological application. Electronic Journal of 
Biotechnology 31:48-56 https://doi.org/10.1016/j.ejbt.2017.11.001.

Rogers BF, Tate III RL. 2001. Temporal analysis of the soil microbial community along a toposequence in pineland soils. Soil Biology and Biochemistry 33:1389-1401 https://doi.org/10.1016/S0038-0717(01)00044-X.

Schinner F, Öhlinger R, Kandeler DE, Margesin R. 1995. Methods in Soil Biology. Berlin: Springer Verlag, 386-389.

Shah F, Nicolás C, Bentzer J, Ellström M, Smits M, Rineau F, Canbäck B, Floudas D, Carleer R, Lackner G, Braesel J, Hoffmeister D, Henrissat B, Ahrén D, Johansson T, Hibbett DS, Martin F, Persson P, Tunlid A. 2016. Ectomycorrhizal fungi decompose soil organic matter using oxidative mechanisms adapted from saprotrophic ancestors. New Phytologist 209:1705-1719 https://doi.org/10.1111/nph. 13722.

Shao P, Liang C, Lynch L, Xie H, Bao X. 2019. Reforestation accelerates soil organic carbon accumulation: Evidence from microbial biomarkers. Soil Biology and Biochemistry 131: 182-190 https://doi.org/10.1016/j.soilbio.2019.01.012.

Shridhar B S. 2012. Review: Nitrogen fixing microorganisms. Int J Microbiol Res 3: 46-52 10.5829/idosi.ijmr.2012.3.1.61103

Sorokin D Y, Lücker S, Vejmelkova D. 2012. Nitrification expanded: discovery, physiology and genomics of a nitrite-oxidizing bacterium from the phylum Chloroflexi. The ISME journal 6: 2245 10.1038/ismej.2012.70.

Spohn M, Zavišić A, Nassal P, Bergkemper F, Schulz S, Marhan S, MichaelSchloter M, Kandeler E, Polle A. 2018. Temporal variations of phosphorus uptake by soil microbial biomass and young beech trees in two forest soils with contrasting phosphorus stocks. Soil Biology and Biochemistry 117:191-202 https://doi.org/10.1016/j.soilbio. 2017.10.019.

Toju H, Yamamoto S, Sato H. 2013. Community composition of root-associated fungi in a $Q$ uercus-dominated temperate forest: "codominance" of mycorrhizal and root-endophytic fungi. Ecology and Evolution 3: 1281-1293 https://doi.org/10.1002/ece3.546.

Vance ED, Brookes PC, Jenkinson DS. 1987. An extraction method for measuring soil microbial biomass C. Soil Biology and Biochemistry 19:703-707 https://doi.org/10.1016/0038-0717(87)90052-6.

Wang C, Wang G, Wang Y, Rashid R, Ma L, Hu L, Luo Y. 2016. Fire alters vegetation and soil microbial community in alpine meadow. Land Degradation \& Development 27:13791390 https://doi.org/10.1002/ldr.2367.

Wang XH, Kent M, Fang XF. 2007. Evergreen broad-leaved forest in Eastern China: its ecology and conservation and the importance of resprouting in forest restoration. Forest Ecology and Management 245:76-87 https://doi.org/10.1016/j.foreco.2007.03. 043.

Will C, Thürmer A, Wollherr A, Nacke H, Herold N, Schrumpf M, Gutknecht J, Wubet T, 
Buscot F, Daniel R. 2010. Horizon-specific bacterial community composition of german grassland soils, as revealed by pyrosequencing-based analysis of $16 \mathrm{~S}$ rRNA genes. Applied and Environmental Microbiology 76:6751-6759 10.1128/AEM.01063- 10

Zhang W, Qiao W, Gao D, Dai Y, Deng J, Yang G, Han X, Ren G.2018. Relationship between soil nutrient properties and biological activities along a restoration chronosequence of Pinus tabulaeformis plantation forests in the Ziwuling Mountains, China. Catena 161:8595 https://doi.org/10.1016/j.catena.2017.10.021.

Lu W, Shen X, Chen Y.2019. Effects of intercropping peanut on soil nutrient status and microbial activity within young Camellia oleifera plantation. Communications in Soil Science and Plant Analysis 50:1232-1238 https://doi.org/10.1080/00103624.2019.1614600.

Wu F, Li J, Chen Y, Zhang L, Zhang Y, Wang S, Shi X, Li L, Liang J. 2019. Effects of phosphate solubilizing bacteria on the growth, photosynthesis, and nutrient uptake of camellia oleifera Abel. Forests 10:348-358 https://doi.org/10.3390/f10040348.

Xia Y, Wen X, Zhang B, Yang Y. 2018. Diversity and assembly patterns of activated sludge microbial communities: A review. Biotechnology advances 36: 1038-1047 https://doi.org/10. 1016/j.biotechadv.2018.03.005.

Xu J, Zhang Y, Zhang P, Trivedi PT, Riera N, Wang Y, Liu X, Fan G, Tang J, ColettaFilho HD, Cubero J, Deng X, Ancona V, Lu Z, Zhong B, Roper MC, Capote N, Vittoria C, Pietersen G, Vernière C, Al-Sadi AM, Li L, Yang F, Xu X, Wang J, Yang H, Jin T, Wang N. 2018. The structure and function of the global citrus rhizosphere microbiome. Nature Communications 9:4986 10.1038/s41467-018-07343-2.

Yang T, Liu G, Li Y. 2012.Rhizosphere microbial communities and organic acids secreted by aluminum-tolerant and aluminum-sensitive soybean in acid soil. Biology and Fertility of Soils 48: 97-108 10.1007/s00374-011-0608-7.

Youssef NH, Elshahed MS. 2009. Diversity rankings among bacterial lineages in soil. The ISME Journal 3:305-313 https://doi.org/10.1038/ismej.2008.106.

Zhang D, Yan D, Fang W, Fang WS, Huang B. 2019. Chloropicrin alternated with biofumigation increases crop yield and modifies soil bacterial and fungal communities in strawberry production. Science of The Total Environment 675: 615-622 https://doi.org/10.1016/j.scitotenv. 2019.04.222.

Zhang Y, Wang L, Yuan Y, Xu J, Tu C, Fisk C, Zhang W, Chen X, Ritchie D, Hu S. 2018. Irrigation and weed control alter soil microbiology and nutrient availability in North Carolina Sandhill peach orchards. Science of the Total Environment 615: 517-525 https://doi.org/10. 1016/j.scitotenv.2017.09.265.

Zhou J, Ai Z, Wang H, Niu G. 2019. Phosphorus alleviates aluminum toxicity in camellia oleifera seedlings. International Journal of Agriculture \& Biology 21:237-243 
$528 \quad$ 10.17957/IJAB/15. 0886.

529 Zifčáková L, Větrovský T, Howe A, Baldrian P. 2016. Microbial activity in forest soil reflects 530 the changes in ecosystem properties between summer and winter. Environmental 531 Microbiology 18:288-301 https://doi.org/10.1111/1462-2920.13026. 


\section{Table $\mathbf{1}$ (on next page)}

Physicochemical, enzyme activities and microbial biomass characteristics of the soil samples

* indicates that the difference between the different treatments in the same season is significant at the 0.05 level. Different letters indicate that the same treatment differs significantly at the 0.05 level in different seasons. $\mathrm{R}$ (rhizosphere soil); $\mathrm{N}$ (non-rhizosphere soil); OM (organic matter); AN (alkali nitrogen); AP (available phosphorus). The same below. 
1 Table 1 Physicochemical, enzyme activities and microbial biomass characteristics of the soil

2 samples

\begin{tabular}{|c|c|c|c|c|c|}
\hline Item & Soil & Spring & Summer & Autumn & Winter \\
\hline \multirow[b]{2}{*}{$\mathrm{pH}$} & $\mathrm{R}$ & $4.97 \pm 0.19 b$ & $4.94 \pm 0.27 \mathrm{~b}$ & $4.95 \pm 0.87 \mathrm{~b}$ & $5.16 \pm 0.04 a$ \\
\hline & $\mathrm{N}$ & $\begin{array}{c}5.56 \pm 0.35 \mathrm{a} \\
*\end{array}$ & $5.20 \pm 0.29 b^{*}$ & $5.33 \pm 1.14 b^{*}$ & $5.35 \pm 0.06 b^{*}$ \\
\hline \multirow{2}{*}{$\begin{array}{c}\mathrm{OM} \\
\left(\mathrm{g} \cdot \mathrm{kg}^{-1}\right)\end{array}$} & $\mathrm{R}$ & $\begin{array}{c}26.56 \pm 6.08 \\
c^{*}\end{array}$ & $34.24 \pm 6.11 \mathrm{a}^{*}$ & $31.22 \pm 5.87 b^{*}$ & $23.36 \pm 1.48 \mathrm{~d}^{*}$ \\
\hline & $\mathrm{N}$ & $7.61 \pm 4.05 c$ & $15.20 \pm 5.06 \mathrm{a}$ & $8.23 \pm 0.86 \mathrm{~b}$ & $6.67 \pm 2.94 \mathrm{~d}$ \\
\hline \multirow{2}{*}{$\begin{array}{c}\mathrm{AN} \\
\left(\mathrm{g} \cdot \mathrm{kg}^{-1}\right)\end{array}$} & $\mathrm{R}$ & $\begin{array}{c}88.71 \pm 22.0 \\
4 d^{*}\end{array}$ & $\begin{array}{c}116.51 \pm 34.67 b \\
*\end{array}$ & $\begin{array}{c}129.91 \pm 29.47 \mathrm{a} \\
*\end{array}$ & $\begin{array}{c}102.25 \pm 28.54 \mathrm{c} \\
*\end{array}$ \\
\hline & $\mathrm{N}$ & $\begin{array}{c}32.16 \pm 22.9 \\
4 \mathrm{~d}\end{array}$ & $73.08 \pm 42.05 b$ & $80.39 \pm 26.21 \mathrm{a}$ & $53.81 \pm 14.87 \mathrm{c}$ \\
\hline \multirow{2}{*}{$\begin{array}{c}\mathrm{AP} \\
\left(\mathrm{g} \cdot \mathrm{kg}^{-1}\right)\end{array}$} & $\mathrm{R}$ & $\begin{array}{c}2.33 \pm 3.75 \mathrm{c} \\
*\end{array}$ & $3.21 \pm 0.91 b^{*}$ & $3.96 \pm 3.24 \mathrm{a}^{*}$ & $2.23 \pm 0.02 \mathrm{c}^{*}$ \\
\hline & $\mathrm{N}$ & $1.08 \pm 0.05 \mathrm{c}$ & $1.70 \pm 0.08 \mathrm{~b}$ & $2.06 \pm 0.06 \mathrm{a}$ & $0.54 \pm 0.01 \mathrm{~d}$ \\
\hline \multirow{2}{*}{$\begin{array}{c}\text { Cellulase } \\
\left(\mu \mathrm{mol} \cdot \mathrm{g}^{-1} \cdot \mathrm{h}^{-1}\right)\end{array}$} & $\mathrm{R}$ & $\begin{array}{c}0.28 \pm 0.03 \mathrm{c} \\
*\end{array}$ & $0.47 \pm 0.04 \mathrm{a}^{*}$ & $0.39 \pm 0.05 b^{*}$ & $0.25 \pm 0.04 c^{*}$ \\
\hline & $\mathrm{N}$ & $0.08 \pm 0.07 b$ & $0.28 \pm 0.04 \mathrm{a}$ & $0.26 \pm 0.09 \mathrm{a}$ & $0.07 \pm 0.01 \mathrm{~b}$ \\
\hline \multirow{2}{*}{$\begin{array}{c}\text { Urease } \\
\left(\mu \mathrm{mol} \cdot \mathrm{g}^{-1} \cdot \mathrm{h}^{-1}\right)\end{array}$} & $\mathrm{R}$ & $\begin{array}{c}10.50 \pm 4.04 \\
\mathrm{~b}^{*}\end{array}$ & $15.11 \pm 2.41 \mathrm{a}^{*}$ & $16.52 \pm 2.64 \mathrm{a}^{*}$ & $7.40 \pm 0.26 c^{*}$ \\
\hline & $\mathrm{N}$ & $7.73 \pm 4.58 b$ & $8.22 \pm 2.75 \mathrm{a}$ & $9.14 \pm 3.58 \mathrm{a}$ & $7.00 \pm 0.02 \mathrm{~b}$ \\
\hline \multirow{2}{*}{$\begin{array}{c}\text { Acid } \\
\text { phosphatase } \\
\left(\mu \mathrm{mol} \cdot \mathrm{g}^{-1} \cdot \mathrm{h}^{-1}\right)\end{array}$} & $\mathrm{R}$ & $\begin{array}{c}6.10 \pm 2.18 \mathrm{c} \\
*\end{array}$ & $9.84 \pm 0.86 \mathrm{a}^{*}$ & $7.76 \pm 1.24 \mathrm{~b}^{*}$ & $5.79 \pm 1.40 \mathrm{~d}^{*}$ \\
\hline & $\mathrm{N}$ & $3.56 \pm 0.41 b$ & $5.03 \pm 0.55 \mathrm{a}$ & $4.37 \pm 0.57 \mathrm{a}$ & $3.06 \pm 0.26 \mathrm{~b}$ \\
\hline \multirow{2}{*}{$\begin{array}{c}\mathrm{MBC} \\
\left(\mathrm{mg} \cdot \mathrm{kg}^{-1}\right)\end{array}$} & $\mathrm{R}$ & $\begin{array}{c}127.23 \pm 31 \\
56 \mathrm{~d}^{*}\end{array}$ & $\begin{array}{c}268.54 \pm 41.35 \mathrm{a} \\
*\end{array}$ & $\begin{array}{c}232.23 \pm 38.76 b \\
*\end{array}$ & $\begin{array}{c}159.23 \pm 26.54 \mathrm{c} \\
*\end{array}$ \\
\hline & $\mathrm{N}$ & $\begin{array}{c}68.17 \pm 12.4 \\
7 \mathrm{~d}\end{array}$ & $115 \pm 24.86 \mathrm{a}$ & $101 \pm 20.63 b$ & $81.3 \pm 15.85 \mathrm{c}$ \\
\hline \multirow{2}{*}{$\begin{array}{c}\mathrm{MBN} \\
\left(\mathrm{mg} \cdot \mathrm{kg}^{-1}\right)\end{array}$} & $\mathrm{R}$ & $\begin{array}{c}31.24 \pm 8.56 \\
c^{*}\end{array}$ & $52.24 \pm 12.27 \mathrm{a}^{*}$ & $44.23 \pm 10.57 b^{*}$ & $18.53 \pm 6.52 \mathrm{~d}^{*}$ \\
\hline & $\mathrm{N}$ & $\begin{array}{c}15.31 \pm 2.54 \\
\mathrm{c}\end{array}$ & $28.25 \pm 6.21 \mathrm{a}$ & $21.24 \pm 8.55 b$ & $10.37 \pm 2.33 d$ \\
\hline \multirow{2}{*}{$\begin{array}{c}\mathrm{MBP} \\
\left(\mathrm{mg} \cdot \mathrm{kg}^{-1}\right)\end{array}$} & $\mathrm{R}$ & $\begin{array}{c}1.57 \pm 0.07 \mathrm{~b} \\
*\end{array}$ & $3.16 \pm 0.08 \mathrm{a}^{*}$ & $2.92 \pm 0.04 \mathrm{a}^{*}$ & $1.12 \pm 0.32 \mathrm{c}^{*}$ \\
\hline & $\mathrm{N}$ & $0.94 \pm 0.05 \mathrm{~b}$ & $1.63 \pm 0.15 \mathrm{a}$ & $1.15 \pm 0.93 b$ & $0.62 \pm 0.02 \mathrm{c}$ \\
\hline
\end{tabular}

3 Note: $*$ indicates that the difference between the different treatments in the same season is 4 significant at the 0.05 level. Different letters indicate that the same treatment differs significantly 5 at the 0.05 level in different seasons. R (rhizosphere soil); $\mathrm{N}$ (non-rhizosphere soil); OM (organic 
6 matter); AN (alkali nitrogen); AP (available phosphorus). The same below. 7 
Figure 1

Average well color development (AWCD) of soil microbial community in C. oleifera soil changes with culture time

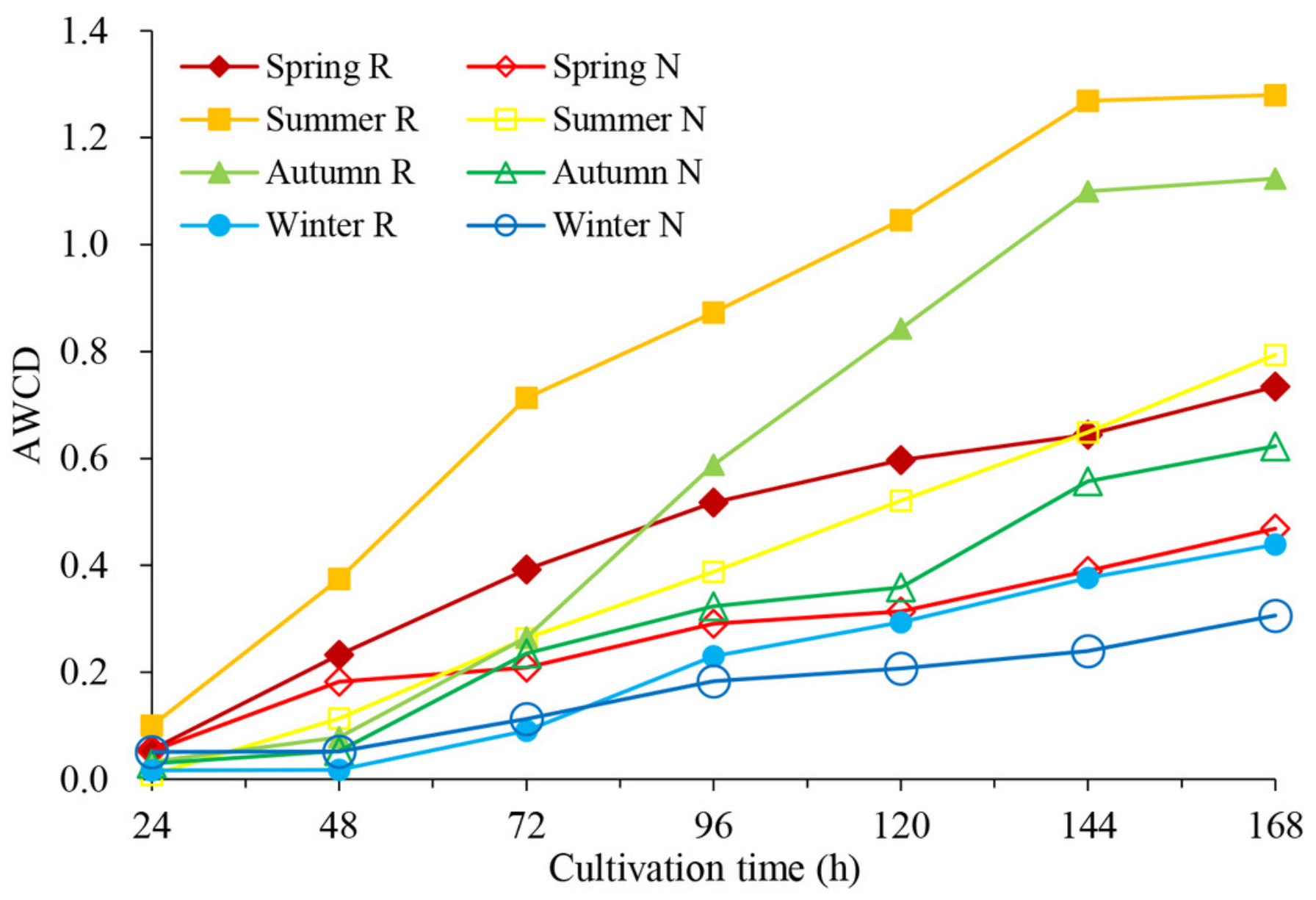


Figure 2

Substrates utilization pattern in soil microorganisms

I (Esters) II (Saccharides) III (Amines) IV (Alcohols) V (acids) VI (Amino acids).(A)Spring;(B)Summer;(C)Autumn;(D)Winter.
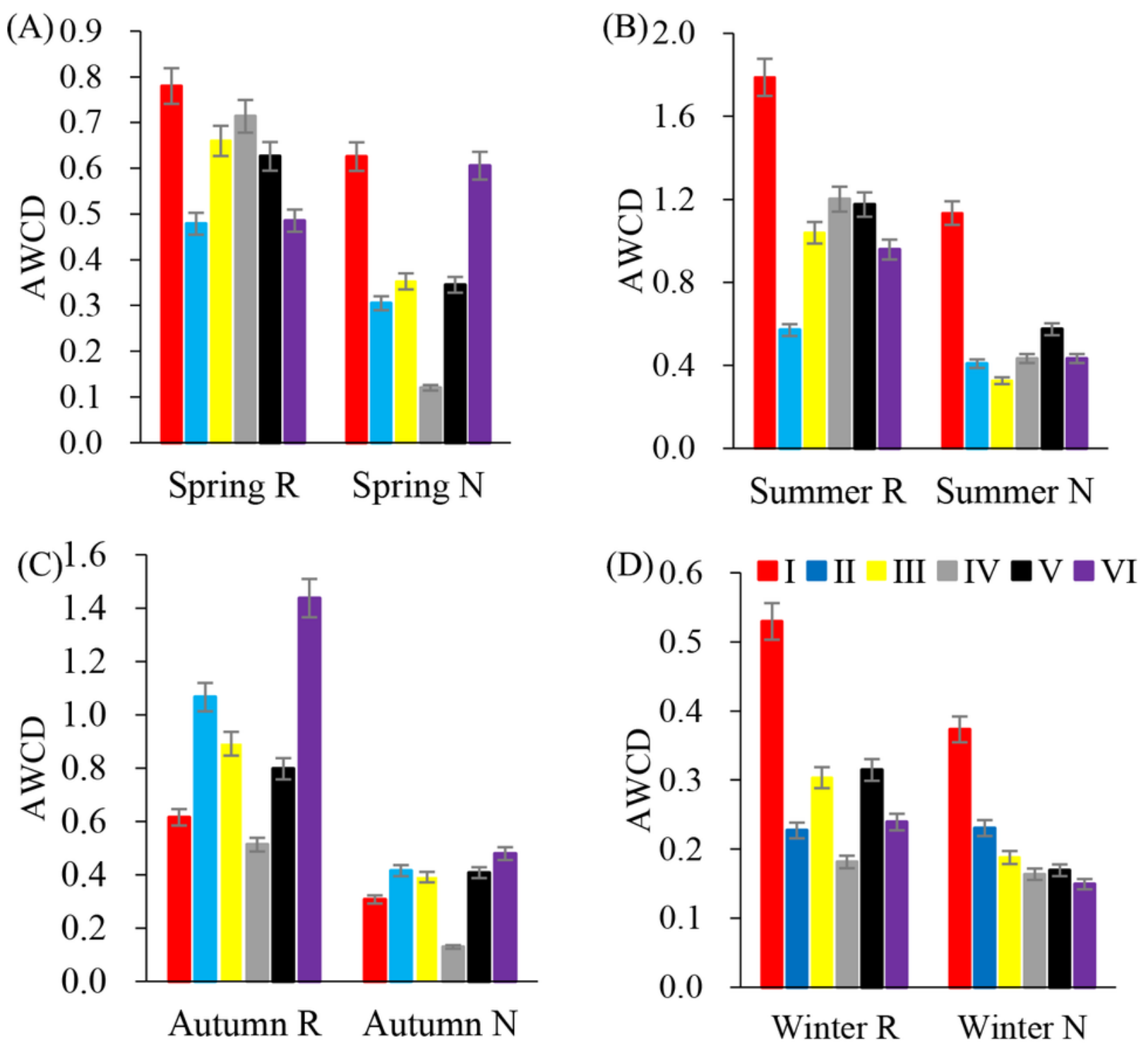
Figure 3

Rarefaction curves of different soil microbial communities

(A) Bacterial community;(B) Fungal community.

(A) Rarefaction curves

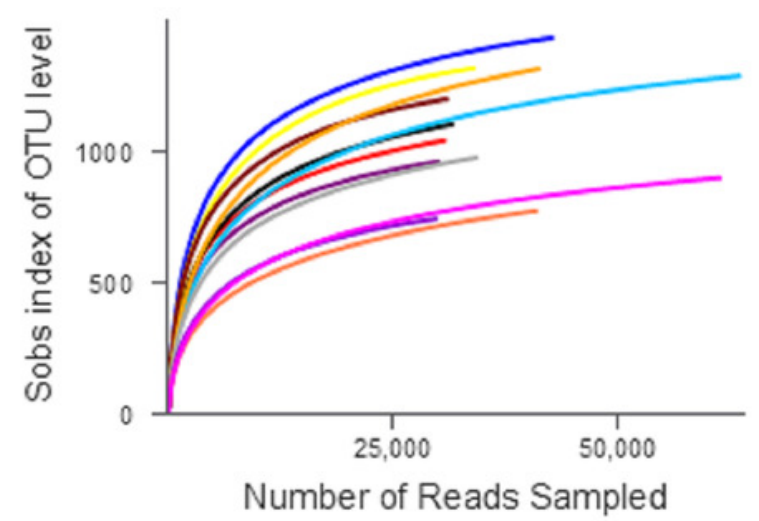

(B) Rarefaction curves

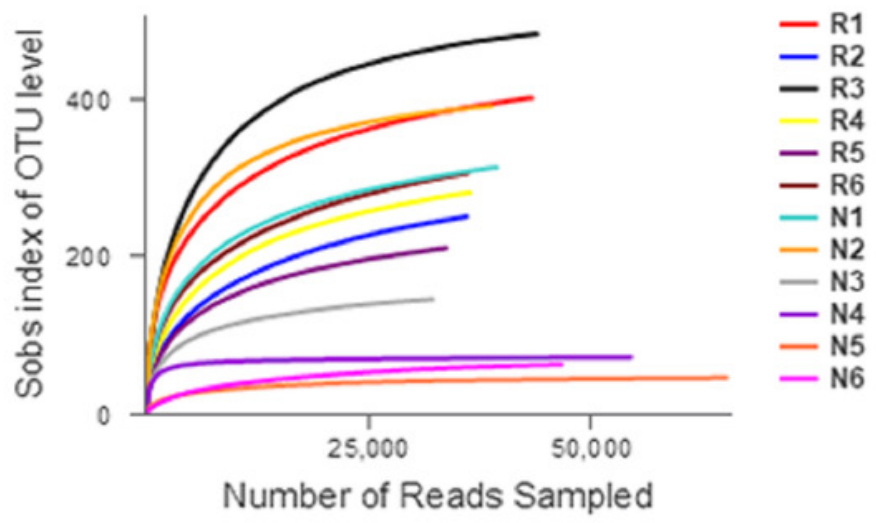


Figure 4

Hierarchical clustering tree of different soil microorganisms at OTU level

(A) Bacterial community;(B) Fungal community.

(A)

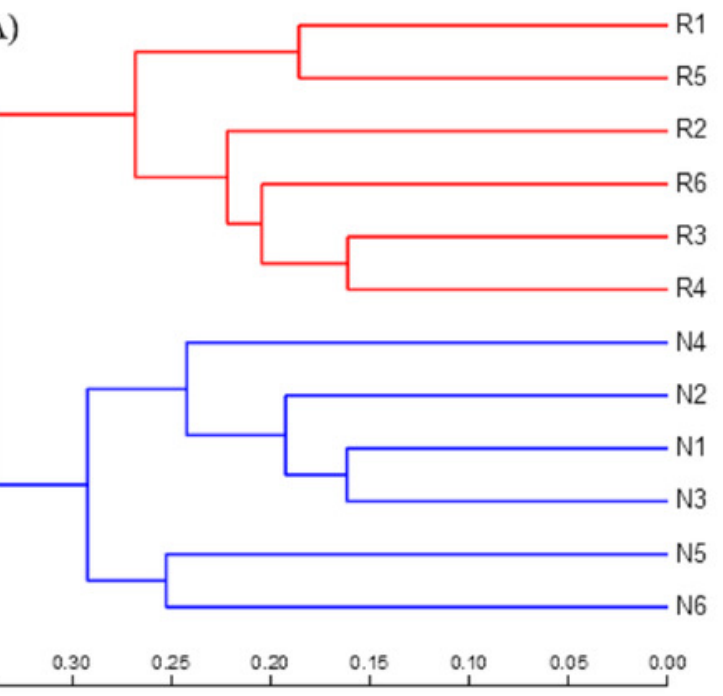

(B)

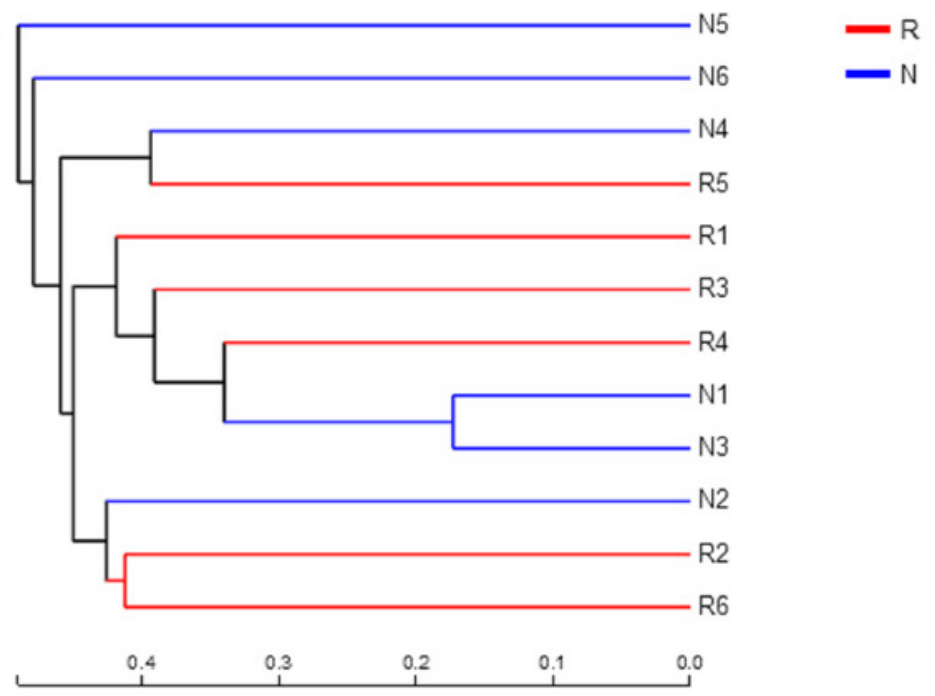


Figure 5

Principal component analysis of different soil microorganisms

(A) Bacterial community;(B) Fungal community.
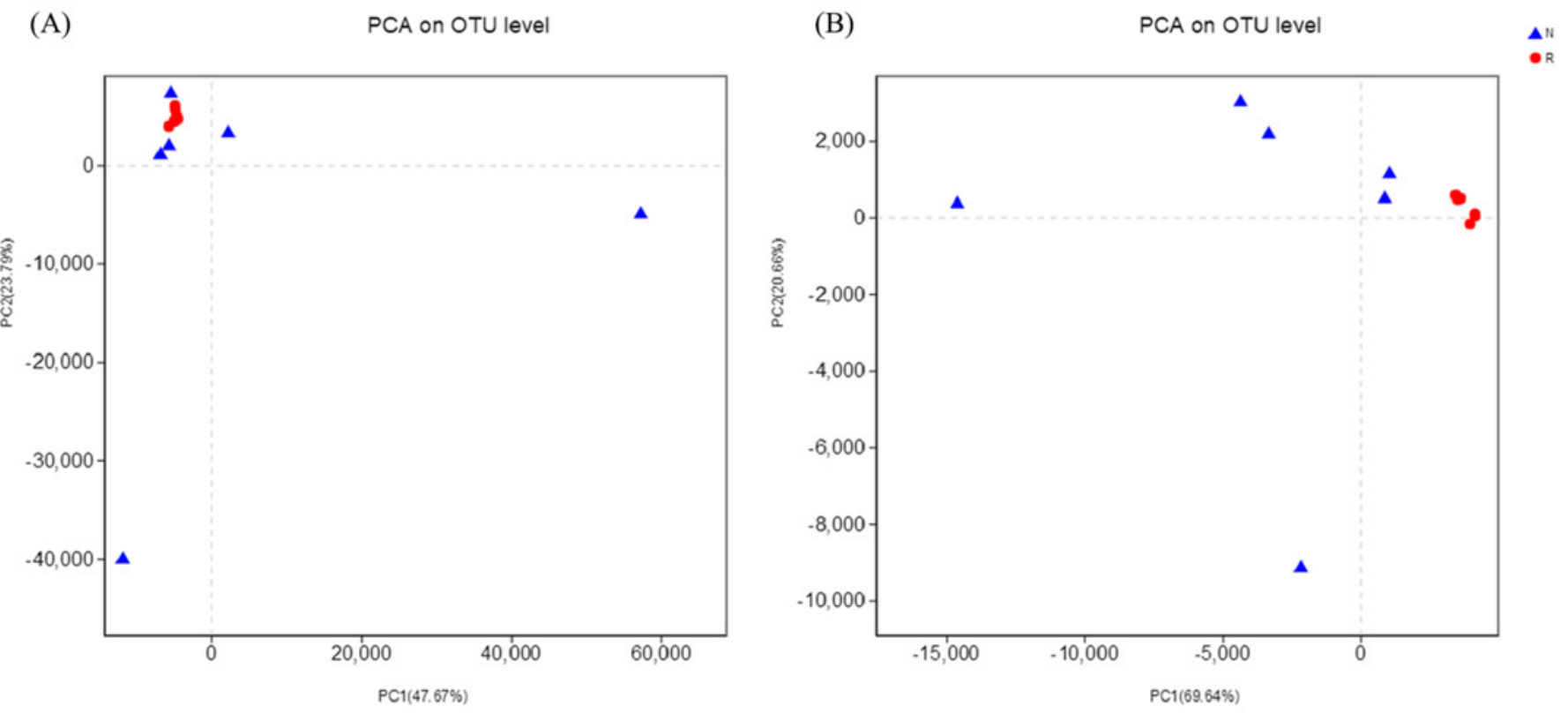
Figure 6

Different soil microbes OUT Wayne diagram

(A) Bacterial community;(B) Fungal community.

(A)

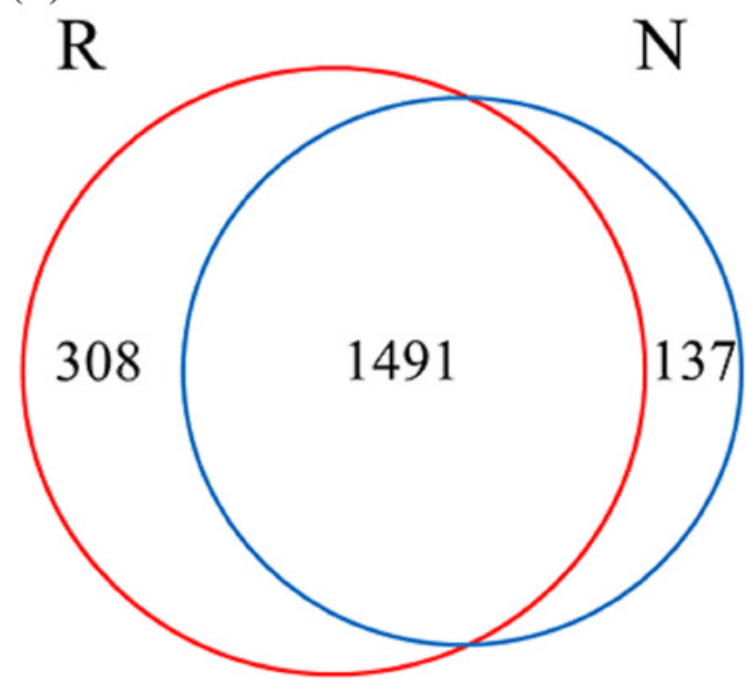

(B)

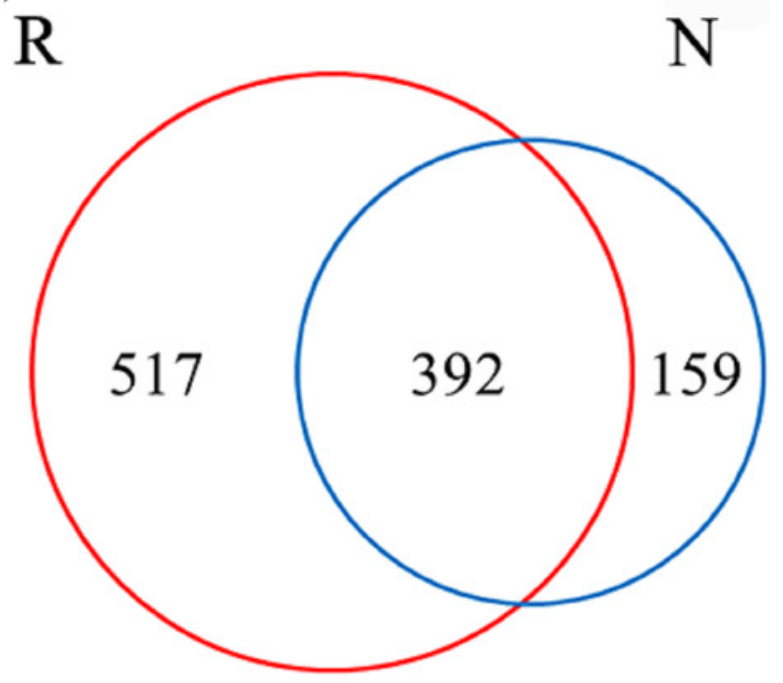


Figure 7

Abundance distribution of different soil microorganisms at the phylums level

(A) Bacterial community;(B) Fungal community.

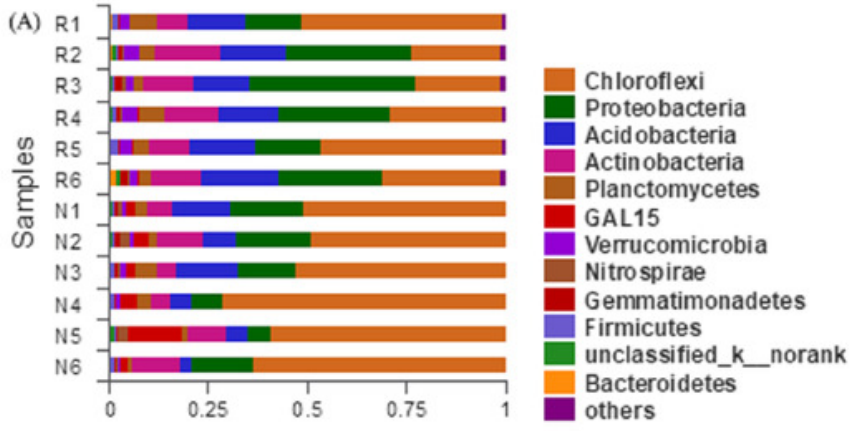

Percent of community abundance on Phylum level

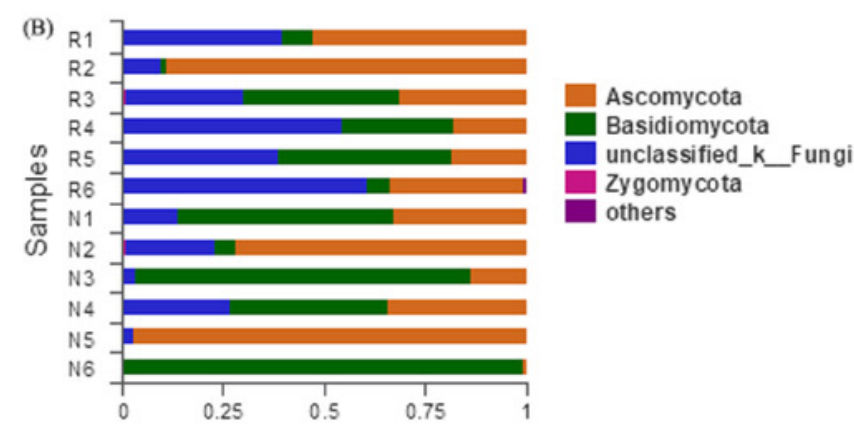

Percent of community abundance on Phylum level 


\section{Figure 8}

Abundance distribution of different soil microorganisms at the genus level

(A) Bacterial community;(B) Fungal community.
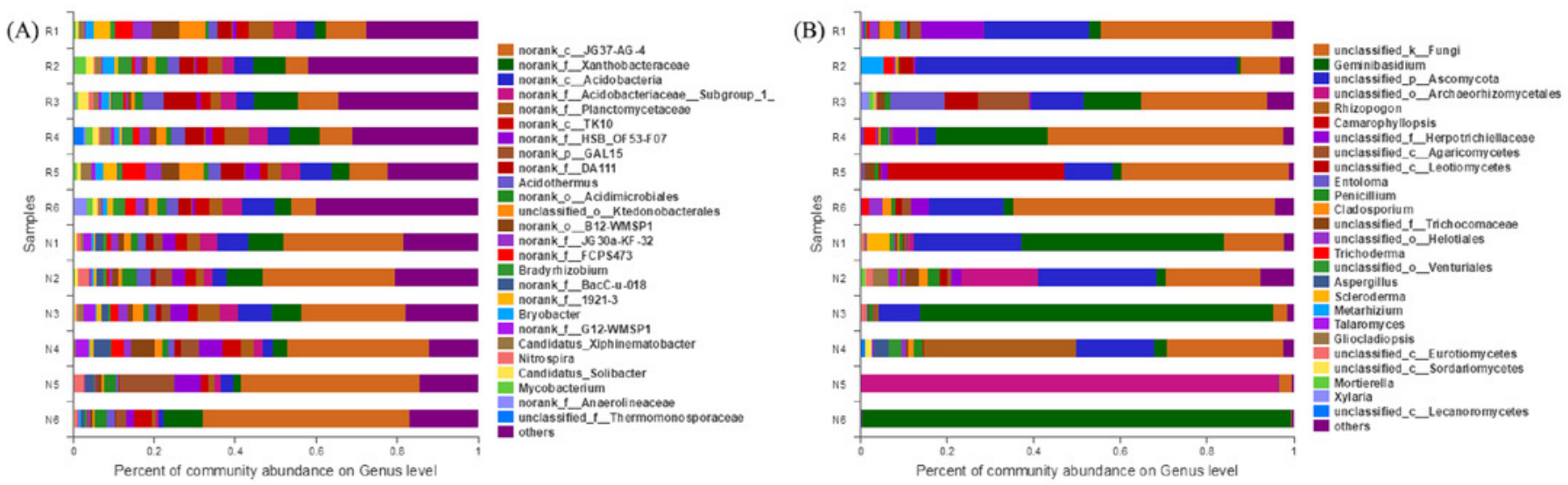


\section{Figure 9}

Spearman correlation heatmap of soil microorganisms

(A) Bacterial community;(B) Fungal community. The corresponding value of heat map is Spearman corralation coefficient where " $r$ " value is between -1 and $1, r<0$ is negative correlation, $r>0$ is positive correlation. marked * indicates significance test $0.01<P \leq 0.05$, marked $* *$ indicates significance test $0.001<\mathrm{P} \leq 0.01$, marked $* * *$ indicates significance test $P \leq 0.001$.

(A)

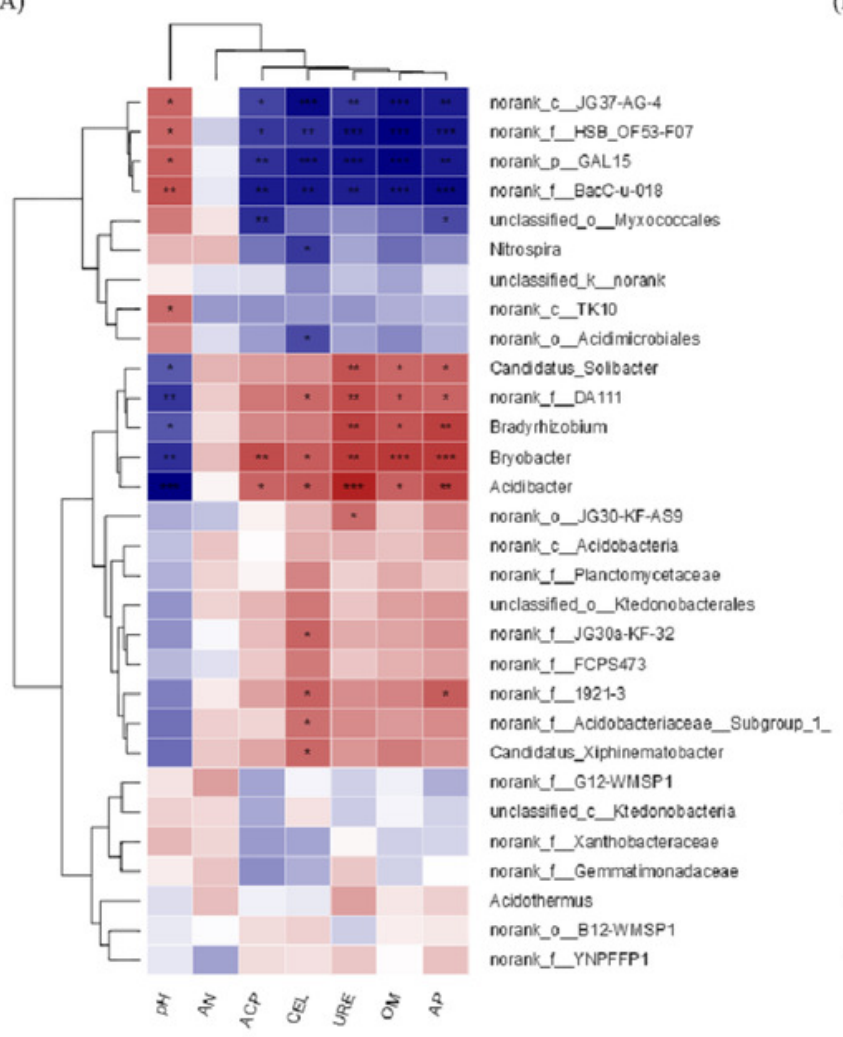

(B)

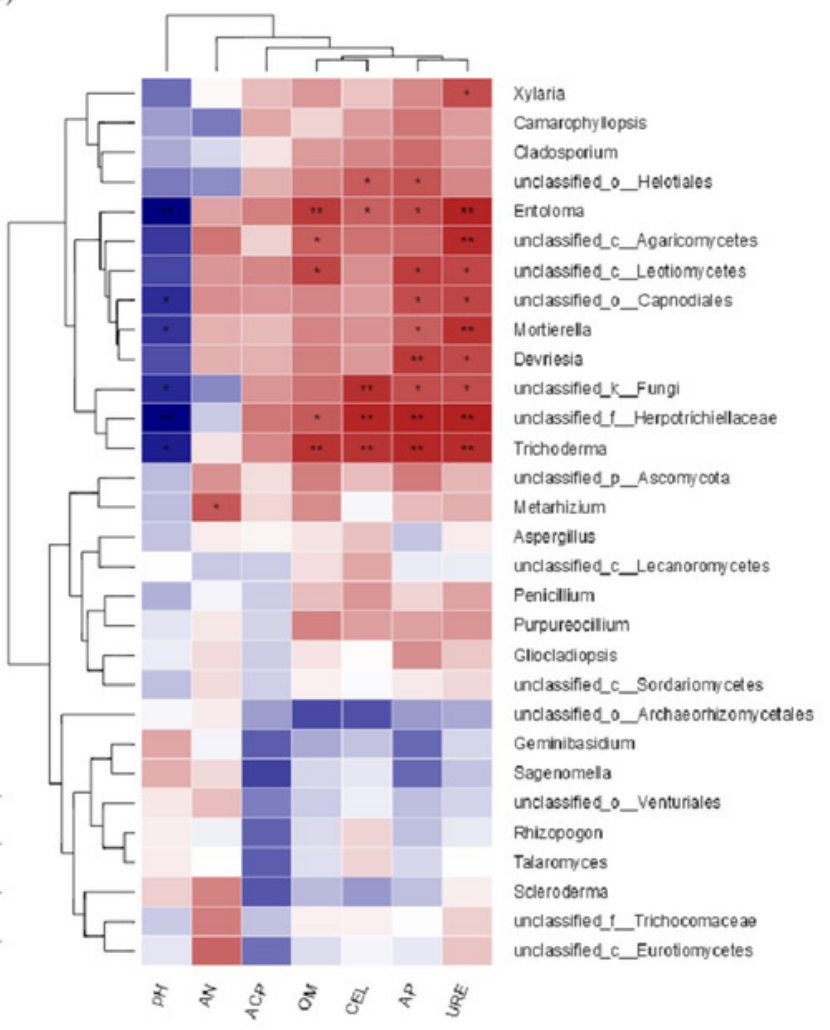

